\title{
Microwave Drying of Rangeland Forage Samples
}

\author{
GERALD E. SCHUMAN AND FRANK RAUZI
}

\section{Abstract}

This study was conducted to compare the effectiveness of microwave drying with that of conventional forced-air oven drying of rangeland forage species. The data show that a microwave oven can dry grass forage samples for biomass production estimates without significantly affecting their nitrogen or phosphorus levels. Drying in a microwave for $\mathbf{1 0}$ minutes was comparable to drying in a forced air oven at $55^{\circ} \mathrm{C}$ for 24 hours.

In range surveys, mine reclamation permit programs, and other range forage evaluations, large numbers of relatively small clipped forage samples must be dried. Because of the locations of these surveys and programs, many of the workers do not have access to ovens of the size or number capable of drying these samples.

Microwave radiation and other drying methods have been evaluated for stopping microbial and physiological processes and for their effects on the chemical components of plant materials (Darrah et al. 1977; Mayland 1968; Mayland et al. 1978). Mayland et al. $(1978)$ evaluated the effect of freeze drying and oven drying at 40 , 56,70 or $100^{\circ} \mathrm{C}$ on the extractable phosphorus (P) in alfalfa and sugarbeets. They concluded that the freeze drying, which caused no loss in dry matter, also caused less organic $\mathbf{P}$ hydroloysis than did oven drying. Wolf and Carson (1973) reported that microwave heating of alfalfa samples for $\mathbf{3 0}$ seconds, followed by forced-air drying was adequate to inactivate respiration. Microwave treat-

The authors are soil scientists, U.S. Department of Agriculture, SEA-AR, High Plains Grasslands Research Station, 8408 Hildreth Rd., Cheyenne, Wyoming 82001 and Laramie, Wyoming, respectively.

This article is a contribution from the SEA-AR, U.S. Dep. Agr. in cooperation with the Wyoming Agricultural Experiment Station, published as Paper No. JA 1055 , Journal Series, Wyoming Agricultural Experiment Station. This research was supported in part by funds from the Environmental Protection Agency, Interagency Agreement: EPA-IAG-D5-E763. ment resulted in similar nonstructural carbohydrates in the tissue when compared to freeze-dried material.

Darrah et al. (1977) found that microwave drying caused heat damage to alfalfa and an orchardgrass-ladino clover mixture after only 12 minutes and 2 minutes of exposure, respectively. Also, levels of acid-detergent-insoluble nitrogen $(\mathrm{N})$ were increased when the alfalfa and grass-clover mixture were exposed to microwave drying. However, drying plant material at $100^{\circ} \mathrm{C}$ in forced air ovens caused more heat damage than microwave drying. Some state regulatory agencies are requiring that forage samples be d ried at $110^{\circ} \mathrm{C}$, which is undoubtedly resulting in heat damage and possible carbon loss.

We conducted this study to compare the effectiveness of microwave and standard ovens for drying of rangeland forage species. Microwave drying could be very useful for personnel who are required to dry many herbage samples at remote locations to evaluate whether mine reclamation meets the state and federal requirements.

\section{Materials and Methods}

Samples of a native grass mixture [western wheatgrass (Agropyron smithii Rydb.), blue (Bouteloua gracilis (H.G.K.) Lag. ex Griffiths), buffalograss (Buchloe dactyloides (Nutt.) Englem.)] and of crested wheatgrass (Agropyron cristatum (L.) Gaertn.) were collected in mid-June and mid-August 1979 at the High Plains Grasslands Research Station, Cheyenne, Wyoming. Sample sizes were about the same as would be harvested from native range sites and crested wheatgrass seedings using a $1.92-\mathrm{ft}^{2}\left(0.18-\mathrm{m}^{2}\right)$ framc. The sample weights for native and crested wheatgrass were 30 and $60 \mathrm{~g}$, representing yields of 1,680 and $3,360 \mathrm{~kg} / \mathrm{ha}$, respectively.

Samples clipped in June were placed in small paper bags and dried for 7.5 and 10 minutes in a Litton/Minute Master ${ }^{1}$ micro-

'Use of trade name does not imply end orsement of this product by the USDA, but is used for the information of the reader only.

JOURNAL OF RANGE MANAGEMENT 34(5), September 1981 
Table 1. The comparison of microwave drying and forced air drying on forage moisture content, nitrogen and phosphorus of crested wheatgrass and a native grass mixture.

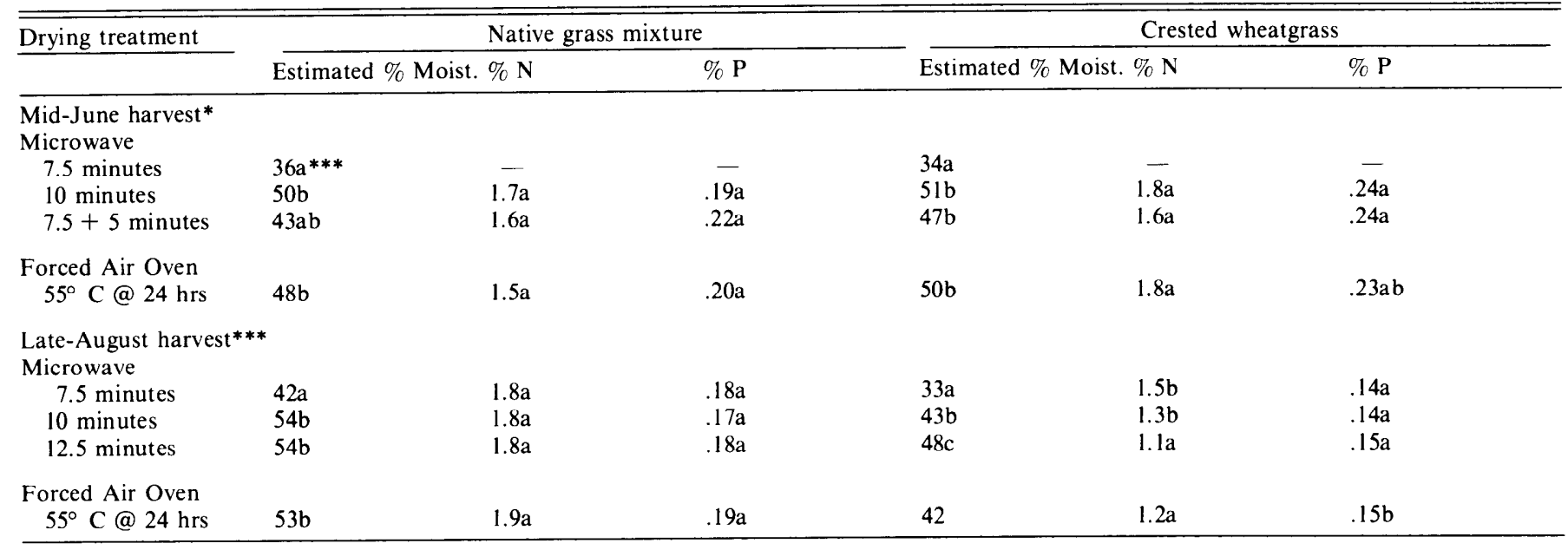

1* Each data value represents a mean of 5 samples.

** Each data value represents a mean of 8 samples.

*** Values with the same letter within columns and harvest date are not significantly different at the $1 \%$ level as tested by Dunca's multiple range test.

wave set at high/roast and compared with samples dried at $55^{\circ} \mathrm{C}$ for 24 hours in a forced air oven. Each species and drying treatment was replicated five times. Samples dried for 7.5 minutes were not dry, so they were dried for an additional 5.0 minutes. The August samples, with eight replications, were placed in small paper bags and dried for $7.5,10$ or 12.5 minutes in the microwave oven or $24 \mathrm{hr}$ in the forced air oven at $55^{\circ} \mathrm{C}$. The August plant material had seed heads present; the crested wheatgrass seed heads were mature and somc threshing occurred.

After drying, the plant samples were ground to pass a 40 -mesh screen. Nitrogen content of the plant material was determined by the micro-Kjeldahl procedure (Schuman et al. 1973) and total plant $P$ was determined by the vanadomolybdophosphoric yellow method (Jackson 1958) on a dry ashed sample.

Percent moisture of the harvested forage, $\mathbf{N}$ and $\mathrm{P}$ data were analyzed by analysis of variance and Duncan's multiple range test to test means for significance.

To evaluate water loss as a function of time, forty-eight, 40-g samples of the native grass mixture were placed in paper bags and eight replicates exposed to $2,4,6,8,10$, and 12 minutes in the microwave respectively. Water loss was determined and percent of potential evaporative water loss plotted as a function of time. Simple linear regression analysis was performed on the data.

\section{Results and Discussion}

Percent moisture, $\mathrm{N}$ content, and total $\mathrm{P}$ content of the plant material were not different following 10 minutes in the microwave or $24 \mathrm{hr}$ in the oven at $55^{\circ} \mathrm{C}$, except for $\mathrm{N}$ and $\mathrm{P}$ contents of the late-August harvest of crested wheatgrass (Table 1). This difference in late-August might have been due to variable threshing of the mature seed and ratio of culms to leaves of the sample. The $\mathbf{N}$ and $\mathbf{P}$ values do not show any consistent trends that can be related to the microwave drying. Species differences were significant; therefore, the test of means was done by species. Differences in $\mathbf{N}$ and $\mathrm{P}$ are also evident between sample dates. The continuous 12.5-minute treatments caused some browning or burning of the late-August samples, resulting in a little greater variability among samples than when dried for 10 minutes. The percent moisture of samples dried for 7.5 minutes in the microwave was significantly less than that of samples dried in the oven at $55^{\circ} \mathrm{C}$ for $24 \mathrm{hr}$. This lower percentage moisture indicated that we had not removed all of the water from the forage, when compared with the $55^{\circ} \mathrm{C}$ oven drying. An additional 5.0 minutes did not result in complete drying of the native grass samples collected in mid-June, probably because much of the energy was absorbed by the water molecules and the time was too short to allow for evaporation. Difference in percent moisture between $55^{\circ} \mathrm{C}$ oven drying and 10 minute microwave drying was greatest for the mid-Junc harvest samples of the native grasses. These differences were not statistically significant

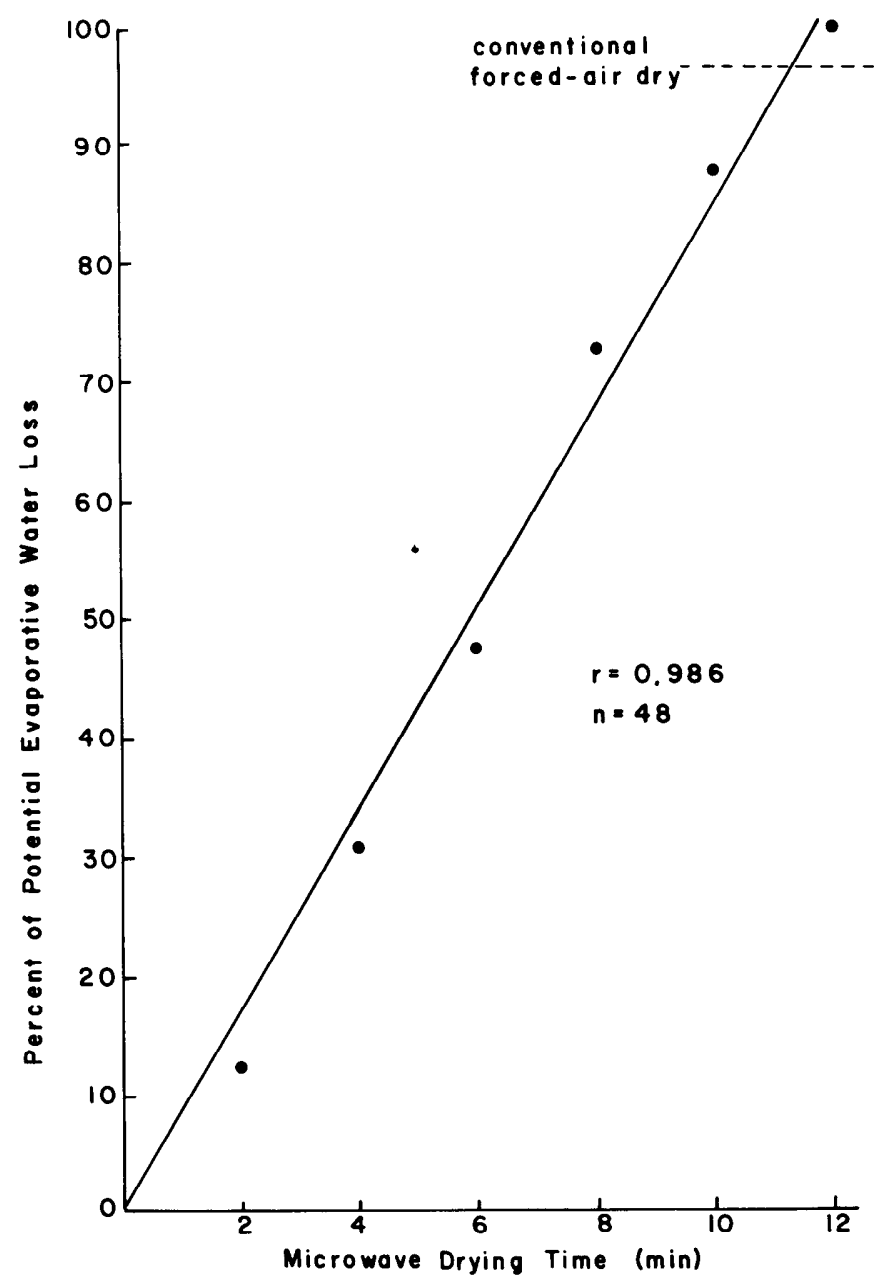

Fig. 1. The relationship hetween microwave exposure time and percent of potential evaporative water loss from forage samples. 
and were smaller than would be expected between randomly selected range sites sampled for biomass.

Water loss from the native grass mixture samples as a function of time is shown in Figure 1. Water loss as a function of time is linear through the range evaluated. Complete dryness as determined by forced-air drying occurred at about 11 minutes of exposure in the microwave. Hofman (1965) pointed out that some measure must be taken to prevent the magnetrons from overloading at the end of the drying period when adequate moisture doesn't exist to absorb the oven's energy output. A time function curve needs to be developed for forages that differ greatly in their water content. This will reduce the chance of operating the microwave for long periods of time after the plant material is dry and prevent charring, which occurs when samples are over exposed. Placement of a small volume of water in the oven is a further precautionary measure that will not only prevent damage to the oven but also reduce charring of the plant material. In developing the time function curve, it is necessary to use the same size sample as when routinely drying forage in the microwave for biomass determination.

This study showed that the microwave oven can be used for drying grass forage samples for biomass production estimates without measureably affecting $\mathrm{N}$ and $\mathrm{P}$ levels of the forages test. Biomass is the factor of primary interest where large numbers of samples are required for evaluating range and reclaimed lands; therefore, the use of a standard microwave oven can save time and money. If other forage quality factors such as in vitro digestibility and acid-detergent-insoluble $\mathrm{N}$ are to be evaluated, the effect of microwave drying on those factors should be determined, since forage species differ in their response to drying.

\section{Literature Cited}

Darrah, C.H. III. P.J. Van Soest, and G.W. Fick. 1977. Microwave treatment and heat damage artifacts in forage. Agron. J. 69:120-121.

Hofman, M.A.J. 1965. Microwave heating as an energy source for the predrying of herbage samples, short communication. Plant and Soil 23(1):145-148.

Jackson, M.L. 1958. Vandomolybdophosphic Yellow Color method in nitric acid system. In: Soil Chemical Analysis 151-153. Prentice-Hall, Inc. Englewood Cliffs, N.J.

Mayland, H.F. 1968. Effect of drying methods on losses of carbon, nitrogen and dry matter from alfalfa. Agron. J. 60:658-659.

Mayland, H.F., D.T. Westermann, and A.R. Florence. 1978. Drying method effects on extractable phosphorus levels in plant tissue. Comm. in Soil Sci. and Plant Analysis 9:551-557.

Schuman, G.E., M.A. Stanley, and D. Knudsen. 1973. Automated total nitrogen analysis of soil and plant samples. Soil Sci. Soc. Amer. Proc. 37:480-481.

Wolf, D.D., and E.W. Carson. 1973. Respiration during drying of alfalfa herbage. Crop Sci. 13:660-662. 